Jurnal Akuntansi dan Manajemen

Vol. 15 No. 2, 2020, Hal.97-105

\title{
PELATIHAN PEMANFAATAN PERANGKAT LUNAK “MIND OWN YOUR BUSINESS (MYOB)- FOR ACCOUNTING V.25 SEBAGAI MEDIA PEMBUKUAN PADA TOKO ONE BANGUNAN KELURAHAN BANDAR BUAT KOTA PADANG
}

\author{
Dita Maretha Rissi 1, Ermatati Hatta ${ }^{2}$, Fitra Oliyan³, Lisa Amelia Herman4 \\ ${ }^{1}$ Jurusan Akuntansi Politeknik Negeri Padang \\ Email: ditamaretharissi@gmail.com \\ ${ }^{2} J u r u s a n$ Akuntansi Politeknik Negeri Padang \\ Email:ermatati.hatta@gmail.com \\ 3 Jurusan Akuntansi Politeknik Negeri Padang \\ oliyan.fitra@gmail.com \\ ${ }^{4}$ Jurusan Akuntansi Politeknik Negeri Padang \\ Email: lisa.ameliaherman@gmail.com
}

\begin{abstract}
Toko One Bangunan is located at Jalan Gadut, Bandar Subdistrict, for 6 employees. Toko One Bangunan was a family business and now has several branches in the city of Padang, but the responsibility has been given to each child. So that the shop in Gadut is held by Mr. Alfi. To be able to find out business results and conduct business analysis, financial reports or business results reports through bookkeeping are sufficient and suitable for business lines. However, the One Bangunan store business which is managed by Mr. Alfi has not carried out adequate financial accounting in accordance with MSME-based records. Mr. Alfi only has 1 small book which is used as a record of incoming money per day. So it will be difficult for business owners to know the development of this business and also not be able to make proper economic decisions because no financial reports are produced as the basis for the analysis. This condition is also related to the closure of Mr. Alfi's furniture business, which was established in 2009. One of the reasons for this is the closure of the furniture business because there is no bookkeeping. Meanwhile, for every sale, there are some customers who do not immediately pay in cash. So it is difficult for owners to monitor customers who have not paid off their obligations. The purpose of this activity is to help the One Bangunan store business to book its business using Mind Your Own Business (MYOB) for Accounting V.25 software which is very suitable for this type of business to apply. The software offered is very simple to use by beginners and can generate financial reports automatically from the transactions that have been inputted. So that with this computerized bookkeeping can help work quickly and accurately, later business owners can use these financial reports as study material to analyze their business and be able to maintain their business in the future.
\end{abstract}

Keywords: Training, Software, Bookkeeping Media.

\begin{abstract}
Abstrak
Toko One Bangunan beralamat di jalan raya gadut kelurahan Bandar buat memiliki 6 orang karyawan. Toko One Bangunan dulunya merupakan usaha keluarga dan sekarang sudah memiliki beberapa cabang di kota Padang, namun pertanggungjawabnnya sudah diberikan kepada masing-masing anak. Sehingga untuk toko yang berada di gadut ini dipegang oleh Bapak Alfi. Untuk dapat mengetahui hasil usaha dan melakukan
\end{abstract}


analisis usaha sangat dibutuhkan laporan keuangan atau laporan hasil usaha melalui pembukuan yang memadai dan cocok bagi lini bisnis. Namun, usaha toko One Bangunan yang dikelola oleh Bapak Alfi belum melakukan pembukuan keuangan secara memadai sesuai dengan pencatatan berbasis UMKM. Bapak Alfi hanya memiliki 1 buah buku kecil yang digunakan sebagai catatan uang masuk per hari. Sehingga akan kesulitan bagi pemilik usaha mengetahui perkembangan dari usaha ini dan juga tidak bisa melakukan pengambilan keputusan ekonomis yang tepat karena tidak ada laporan keuangan yang dihasilkan sebagai dasar analisis tersebut. Kondisi ini juga berkaitan dengan pernah ditutupnya usaha perabot milik Bapak Alfi yang berdiri tahun 2009. Tutupnya usaha perabot ini salah satunya juga karena tidak adanya pembukuan yang dilakukan. Sementara untuk setiap penjualan, ada beberapa pelanggan yang tidak langsung membayar secara tunai. Sehingga sulit bagi pemilik untuk memantau pelanggan yang belum melunasi kewajibannya. Tujuan dari kegiatan ini adalah membantu usaha toko One Bangunan untuk melakukan pembukuan usahanya menggunakan perangkat lunak Mind Your Own Business (MYOB) for Accounting V.25 yang sangat cocok diterapkan oleh UMKM jenis usaha ini. Perangkat lunak yang ditawarkan ini sangat sederhana untuk digunakan oleh pemula dan dapat menghasilkan laporan keuangan secara otomatis dari transaksi yang telah diinput. Sehingga dengan adanya pembukuan secara komputerisasi ini dapat membantu pekerjaan dengan cepat dan akurat, nantinya pemilik usaha dapat mengunakan laporan keuangan tersebut sebagai bahan kajian untuk menganalisis usahanya dan mampu mempertahankan usahanya dimasa yang akan datang.

Kata Kunci: Pelatihan, Perangkat Lunak, Media Pembukuan.

\section{Pendahuluan}

Usaha mikro, kecil, dan menengah (UMKM) sebagai unit usaha masyarakat harus mampu berinovasi dan menjawab tantangan zaman. Inovasi yang dilakukan perlu diimbangi oleh penguasaan aspek teknologi yang memadai guna meningkatkan efektivitas dan efesiensi proses bisnis, salah satunya pengelolaan pembukuan yang menghasilkan laporan keuangan berbasis komputerisasi. Saat ini dalam berbisnis kebanyakan orang berfokus pada strategi marketingnya, bagaimana agar produk yang dihasilkan laku dipasaran sehingga tidak mengalami kerugian. Namun ada hal yang tidak kalah pentingnya yang tentunya menunjang keberhasilan suatu usaha, hal tersebut adalah pembukuan.

Pembukuan merupakan proses pengumpulan data dan informasi yang berhubungan dengan keuangan usaha secara teratur dan terperinci. Pentingnya pembukuan dalam sebuah bisnis adalah bisa mengetahui progress bisnis yang dijalankan, apakah hasil yang didapat selama ini terkategori menguntungkan atau tidak. Dengan adanya pembukuan, pelaku bisnis dapat mengontrol biaya yang dikeluarkan dalam operasional bisnis tersebut. Melalui pembukuan, pebisnis bisa menyusun dan menyajikan laporan keuangan usahanya yang berguna untuk melihat secara pasti nilai utang piutang, jumlah asset, jumlah produk dan lainnya serta sebagai dasar dalam pengambilan keputusan ekonomis.

Terkait dengan pentingnya pembukuan yang harus dilakukan oleh pelaku bisnis saat ini sekaligus menjawab perkembangan teknologi, pebisnis dapat melakukan pembukuan menggunakan metode komputerisasi serta memilih aplikasi berbasis pembukuan keuangan yang banyak ditawarkan oleh beberapa Negara seperti Singapura, Australia dan Indonesia. Penggunaan pembukuan secara komputerasi ini dapat meningkatkan efektivitas dan efesiensi terhadap kinerja suatu usaha. Banyak hal positif yang dapat diperoleh dengan memilih metode pembukuan secara komputersasi seperti mendapatkan informasi keuangan yang lebih tepat dan akurat, mempercepat pekerjaan, dan media penyimpanan data keuangan yang aman dari kehilangan dan kebakaran jika dibandingkan dengaan 
metode pembukuan manual. Dengan adanya pembukuan dan dukungan dari perangkat lunak ini, pelaku bisnis dapat menyusun dan menyajikan laporan keuangannya melalui pembukuan yang telah dibuat.

(Modugu \& Eragbe, 2018) menyatakan bahwa UMKM memiliki peran penting dalam pengembangan suatu Negara, tetapi status pengelolaan keuangannya masih belum tersaji dengan baik. Pelaku UMKM menganggap bahwa penjualan dan keberadaan uang pada arus kas masih lebih penting daripada pelaporan keuangan secara periodic, hal ini mengakibatkan isi dari laporan keuangan UMKM seringkali tidak lengkap, tidak tercatat dengan rapi, dan tidak mencerminkan status usaha yang sebenarnya (Shields \& Shelleman, 2019). Proses pembukuan keuangan dan penyajian laporan keuangan masih dinilai sulit, terlebih bagi UMKM yang masih beroperasi dengan skala kecil.

Fakta yang terjadi saat ini, masih terdapat beberapa UMKM yang belum melakukan pembukuan secara komputerisasi. Mereka lebih cenderung menggunakan hal yang sudah biasa dalam pengolahan data keuangan seperti pembukuan manual menggunakan sebuah buku yang hanya mencatat uang masuk harian. Masih banyak ditemukan UMKM yang belum paham akan fundamentalnya peran pembukuan dan laporan keuangan. Pembukuan usaha hanya dibuat seadanya, ditulis manual dengan format sederhana dan tidak menggunakan standard dan prinsip akuntansi yang tepat. Akibatnya adalah seringkali terdapat kekeliruan dalam pengambilan keputusan ekonomis terhadap status laba/rugi dari UMKM karena tidak tertibnya pembukuan dan pelaporan keuangan usahanya.

Hal ini disebabkan karena kurangnya pengetahuan sumber daya manusia akan system pembukuan komputerisasi. Tidak sedikit usahawan yang tidak mengetahui berapa keuntungan atau kerugian usaha yang mereka jalankan dikarenakan mereka mencampur adukan biaya dan hasil bisnisnya kedalam satu wadah pembukuan dan menggunakannya untuk keperluan sehari-hari serta minimnya media pembukuan yang dilakukan selama ini. Pembukuan secara manual dan sederhana yang dilakukan pelaku UMKM saat ini mengakibatkan rendahnya kualitas pelaporan keuangan dan kesalahan menganalisis kemajuan dari usaha dan berakibat buruk bagi keberlangsungan usaha dimasa yang akan datang.

Berdasarkan ilustrasi tersebut, pelaku usaha UMKM membutuhkan pemahaman dan bimbingan mengenai pemanfaat perangkat lunak sebagai media pembukuan untuk menunjang kemajuan usaha. Salah satu UMKM yang produktif secara ekonomi di kelurahan Bandar Buat adalah Toko One Bangunan. Toko One Bangunan berada di jalan raya gadut yang telah beroperasi sejak tahun 2009 dan memiliki karyawan sebanyak 6 orang. Omzet per hari dari Toko One Bangunan sekitar lima juta rupiah. Pemilik dari toko ini adalah Bapak Alfi, dimana usaha perdagangan bahan bangunan ini telah lama digeluti. Awalnya usaha ini merupakan usaha milik keluarga, namun tahun 2009 diputuskan untuk membuat cabang di daerah Bandar Buat dan diberikan tanggung jawab kepada anak-anak yang salah satu anaknya adalah Bapak Alfi. Tim penulis pada kegiatan ini tertarik memilih Toko One Bangunan sebagai mitra pada kegiatan Pengabdian Kepada Masyarakat.

Dari survey dan wawancara dengan pemilik usaha yang telah dilakukan penulis, kondisi Toko One Bangunan saat ini masih melakukan pembukuan keuangan secara manual dan sederhana. Pembukuan yang dilakukan oleh pemilik sampai saat ini hanya pada sebuah buku kecil yang mencatat uang masuk dari penjualan per hari. Belum ada pembukuan mengenai jumlah persediaan barang dagang, jumlah mutasi persediaan per hari, jumlah 
asset yang dimiliki, pencatatan beban-beban operasional per hari, hingga tidak adanya laporan mengenai laba atau rugi dari usaha yang dilakukan selama ini. Akibatnya pemilik usaha ini tidak bisa menaksir perkembangan dari usaha yang telah dirintis dari beberapa tahun belakangan.

Selain dari minimnya pembukuan yang dilakukan, satu usaha lainnya dari pemilik mitra ini pernah mengalami kebangkrutan. Usaha yang pernah bangkrut adalah usaha produksi dan penjualan perabot. Pemilik menyatakan bahwa tutupnya lini usaha perabot tersebut salah satunya karena tidak adanya pembukuan yang sistematis. Pemilik mitra mencampur adukan hasil usaha dengan harta pribadi dan mengunakan untuk kebutuhan sehari-hari tanpa adanya pembukuan. Sehingga tidak jelas jumlah uang masuk dan keluar. Ditambah dengan adanya pembayaran secara kredit untuk penjualan perabot, dan tidak diketahui jumlah utang piutang. Sehingga membuat usaha penjualan dan produksi perabot diputuskan ditutup.

Dikarenakan saat ini satu-satunya usaha yang dijalankan oleh pemilik mitra adalah penjualan bahan pembangunan, pemilih usaha harus mempertahankan toko ini demi menunjang perekonomian. Melalui kegiatan pengabdian kepada masyarakat ini dan melihat permsalahan yang terjadi pada mitra ini, pemilik mitra sangat membutuhkan pemahaman dan bimbingan mengenai pembukuan menggunakan perangkat lunak yang cocok digunakan oleh mitra saat ini untuk mempertahankan dan mengembangkan usaha dimasa yang akan. Dengan adanya penerapan pembukuan menggunakan perangkat lunak, diharapkan nantinya mitra ini dapat mengetahui data keuangan usahanya, keuntungan atau kerugian yang diperoleh, dan dapat menggunakan informasi keuangan ini melalui laporan keuangan sebagai dasar pengambilan keputusan ekonomis yang tepat.

Sesuai dengan pengamanat dan analisis saat ini pada mitra Toko One Bangunan, tim penulis menawarkan salah satu aplikasi perangkat lunak yang ada untuk system pembukuan yaitu "Mind Your Own Business (MYOB) for Accounting V.25 sebagai media pembukuan yang cocok digunakan oleh mitra saat ini. Alasan pemilihan aplikasi perangkat lunak ini karena dianggap lebih mudah digunakan bagi pemula dalam melakukan pembukuan keuangan kategori UMKM. Software ini juga bersifat free sehingga bisa di download dan digunakan dengan mudah. Penggunaan software ini dapat membantu pekerjaan mitra dengan cepat dan mudah. Dengan menggunakan software ini, mitra hanya menginputkan transaksi per hari ke dalam formulir yang telah disediakan pada perangkat lunak ini. Fitur yang digunakan pada software ini sangat sederhana dan mudah diaplikasikan bagi pemula. Selain itu, penggunaan aplikasi ini juga mempermudah pengguna untuk menyajikan laporan keuangannya secara otomatis dari transaksi yang diinput. Pemilik dapat melihat data keuangan usahanya dan melihat hasil usahanya secara berkala. Dengan adanya pembukuan dan laporan keuangan yang dihasilkan dari perangkat lunak ini, dapat membantu pemilik usaha dalam pengambilan keputusan dimasa yang akan datang.

Dokumentasi Situasi Toko One Bangunan Kelurahan Bandar Buat Padang 


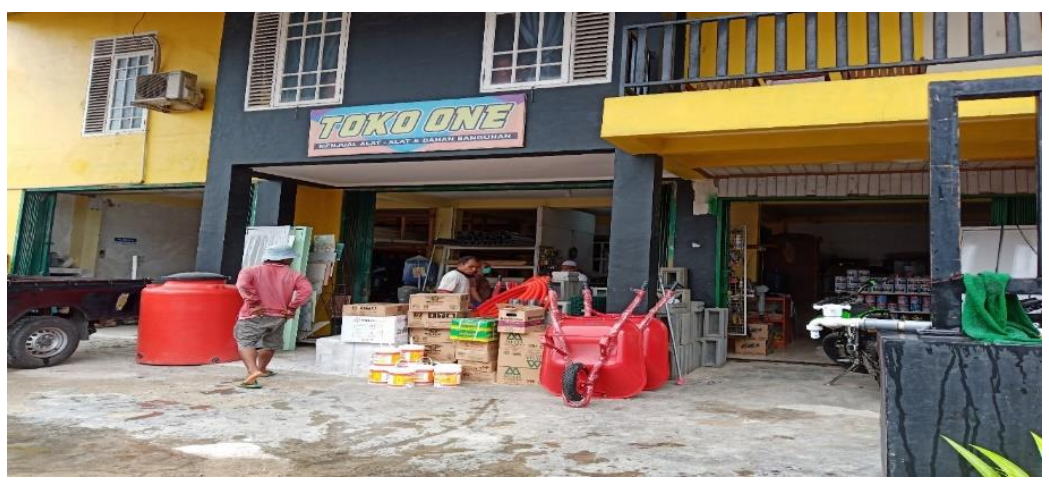

Gambar 1. Situasi Lili Koleksi

\section{Permasalahan Mitra}

Mitra dalam kegiatan pengabdian kepada masyarakat ini adalah UMKM pada Toko One Bangunan yang berada di jalan raya gadut kelurahan Bandar buat kota Padang. Mitra ini bergerak di bidang penjualan bahan bangunan dengan skala menengah kebawah dan sudah beroperasi sejak tahun 2009. Pemilik mitra memperkerjakan enam orang karyawan dengan latar belakang anak putus sekolah dan kategogi disable seperti tunarungu. Jumlah omzet per hari diperkirakan sebesar lima juta rupiah. Pemilik mitra pernah mengalami kebangkrutan usaha dibidang produksi dan penjualan perabot. Diindikasikan bahwa tutupnya usaha tersebut karena tidak adanya pembukuan keuangan yang baik, sehingga minimnya informasi keuangan dan salah dalam mengambil keputusan ekonomis. Satusatunya usaha yang masih dipertahankan sampai saat ini adalah penjualan bahan bangunan yang dirasa semakin hari semakin membutuhkan informasi terkait data keuangan. Kebutuhan ini dirasa sangat penting bagi pemilik mitra karena uang hasil usaha per hari tidak jelas kegunaannya dan masih dicampur dengan keuangan milik pribadi. Sehingga sulit bagi pemilik mitra ini mengetahui data keuangan dari usaha.

Pembukuan yang dilakukan oleh pemilik mitra pada kegiatan ini menggunakan system pembukuan manual, dimana pembukuan dilakukan pada sebuah buku kecil yang hanya menampung catatan uang masuk perharinya. Pembukuan ini sangat berisiko dalam pengambilan keputusan ekonomis bagi pemilik. Karena tidak mencerminkan kondisi yang sebenarnya dari usaha yang dilakukan. Pemilik tidak mengetahui berapa asset yang dimiliki, berapa jumlah barang, berapa total utang piutang dan data keuangan lainnya. Selain itu pemilik mitra ini tidak mengetahui jumlah pasti dari laba atau rugi yang diperoleh dari hasil usaha selama ini. Penggunaan pembukuan secara manual menggunakan buku memiliki tingkat risiko kehilangan dan kerusakan yang tinggi. Pemilik usaha tidak memiliki rekaman data keuangan usaha jika masih menggunakan system manual seperti saat ini.

Menanggapi permasalahan yang dihadapi oleh mitra diatas, tim penulis dari kegiatan ini ingin memberikan solusi untuk mengatasi kondisi tersebut. Solusi yang ditawarkan adalah memberikan pelatihan atas pemanfaatan perangkat lunak "Mind Your Own Busines (MYOB) for Accounting V.25" sebagai media pembukuan keuangan pada mitra yang ditunjuk saat ini yaitu Toko One Bangunan. Pemilihan aplikasi pada perangkat lunak ini karena dirasa lebih mudah diaplikasikan oleh pemula. Penggunaan aplikasi pada perangkat 
lunak ini mampu menampung transaksi sehari-hari dengan jumlah yang besar dan secara otomatis dapat menyajikan laporan keuangan secara berkala sesuai dengan kebutuhan pemilik. Dengan adanya data keuangan melalui pembukuan yang dilakukan, pemilik mitra ini dapat mengetahui posisi usaha saat ini dan dapat menggunakan data keuangan tersebut sebagai dasar dari pengambilan keputusan ekonomisnya. Dan diharapkan untuk jangka waktu yang panjang, mitra ini dapat mengembangkan usaha nya dan bersaing secara sehat serta menunjang perekonomian dengan adanya pembukuan keuangan yang sesuai dengan standar akuntansi UMKM yang berlaku saat ini. Kondisi diatas, dapat disimpulkan masalah prioritas dari mitra adalah sebagai berikut:

1. Masih menggunakan pembukuan secara manual dan sederhana

2. Belum melakukan pembukuan terkait data keuangan

3. Belum pernah melakukan menyusunan laporan keuangan

Sehingga solusi untuk mengatasi permasalah mitra, tim penulis pada kegiatan ini melakukan dengan cara sebagai berikut:

\section{Pemberian Pelatihan}

Pelatihan merupakan metode yang cocok diterapkan untuk mentransfer ilmu pengetahuan mengenai teknik dan prinsip pembukuan keuangan yang sesuai dengan standar akuntansi UMKM saat ini.

2. Demontrasi Penggunaan Aplikasi Perangkat Lunak

Pada kegiatan demontrasi kegiatan pembukuan menggunakan aplikasi yang dipilih yaitu Mind Your Own Busines (MYOB) for Accounting V.25, mitra diberikan kesempatan melakukan uji coba dalam mengoperasikan aplikasi ini sampai mahir.

3. Pendampingan

Selanjutnya mitra didampingi dengan melakukan simulasi praktik secara langsung pembuatan pembukuan mulai dari pencatatan hingga penyajian laporan keuangan. Sehingga pengguna aplikasi ini mampu membantu pekerjaan terkait pembukuan dengan cepat dan akurat. Sehingga nantinya dapat menghasilkan informasi keuangan yang tepat, cepat dan akurat sebagai dasar pengambilan keputusan ekonomis dimasa yang akan datang.

\section{Evaluasi dan Monitoring}

Tim penulis akan melakukan evaluasi dan memonitor mitra secara berkala untuk memastikan bahwa tidak terdapat masalah pada saat mengoperasikan pembukuan menggunakan aplikasi perangkat lunak.

\section{Solusi yang Ditawarkan}

Solusi yang ditawarkan untuk menyelesaikan permasalahan yang dihadapi mitra adalah:

1. Memberikan pelatihan dan pembenahan

2. Memberikan monitoring

\section{Target dan Luaran}

1. Target pada kegiatan ini adalah memberikan ilmu mengenai pembukuan melalui aplikasi MYOB yang cocok diterapkan untuk UMKM.

2. Luaran yang dihasilkan adalah pembukuan yang tepat dan cocok untuk diterapkan oleh usaha UMKM ini. Disamping itu rencana capaian luaran yang ditargetkan dapat dilihat pada tabel dibawah ini : 
Tabel 1. Rencana Target Capaian Luaran

\begin{tabular}{|c|c|c|}
\hline No & Jenis Luaran & Indikator Capaian \\
\hline \multicolumn{3}{|c|}{ Luaran Wajib } \\
\hline 1 & $\begin{array}{l}\text { Publikasi Ilmiah pada Jurnal ber ISSN/Prosiding Jurnal } \\
\text { Nasional1 }^{1)}\end{array}$ & Accepted/Summitted \\
\hline 2 & Publikasi pada media masa cetak/online/repocitory $\mathrm{PT}^{6)}$ & Published \\
\hline 3 & $\begin{array}{l}\text { Peningkatan daya saing (peningkatan kualitas, kuantitas, } \\
\text { serta nilai tambah barang, jasa, diversifikasi produk, atau } \\
\text { sumber daya lainnya) }{ }^{4)}\end{array}$ & Penerapan \\
\hline 4 & $\begin{array}{l}\text { Peningkatan penerapan iptek di masyarakat (mekanisme, } \\
\text { IT, dan manajemen) }{ }^{4} \text { ) }\end{array}$ & Penerapan \\
\hline 5 & $\begin{array}{l}\text { Perbaikan tata nilai masyarakat (seni budaya, sosial, } \\
\text { politik, keamanan, ketentraman, pendidikan, kesehatan) }\end{array}$ & Sudah dilaksanakan \\
\hline \multicolumn{3}{|c|}{ Luaran Tambahan } \\
\hline 1 & Publikasi di jurnal internasional ${ }^{1)}$ & Tidak Ada \\
\hline 2 & $\begin{array}{l}\text { Jasa; rekayasa sosial, metode atau sistem, } \\
\text { produk/barang5) }\end{array}$ & Tidak Ada \\
\hline 3 & Inovasi baru TTG5) & Tidak Ada \\
\hline 4 & $\begin{array}{l}\text { Hak kekayaan intelektual (Paten, Paten sederhana, Hak } \\
\text { Cipta, Merek } \\
\text { dagang, Rahasia dagang, Desain Produk Industri, } \\
\text { Perlindungan Varietas } \\
\text { Tanaman, Perlindungan Desain Topografi Sirkuit } \\
\text { Terpadu) }{ }^{3)}\end{array}$ & Tidak Ada \\
\hline 5 & Buku ber ISBN6) & Tidak Ada \\
\hline 6 & Video & Published \\
\hline
\end{tabular}

\section{Metode Pelaksanaan}

Metode pelaksanaan dalam kegiatan Pengabdian Kepada Masyarakat ini akan dibagi menjadi tiga tahap, yaitu tahap awal, tahap pelaksanaan, dan tahap akhir. Pada tahap awal dilaksanakan survei dan wawancara secara langsung dengan pemilik dari Toko One Bangunan. Hal ini bertujuan untuk mengetahui gambaran mengenai kondisi dan permasalahan yang terjadi selama ini. Pada tahap kedua akan dilakukan tahap pelaksanaan berupa pemberian pelatihan, demontrasi dan pendampingan kegiatan mengenai pemanfaatan perangkat lunak "Mind Your Own Busines (MYOB) for Accounting V.25" sebagai media pembukuan. Kegiatan pelatihan ini bertujuan untuk meningkatkan dan mengembangkan serta memperbaiki system pembukuan pada Toko One Bangunan. Dengan penerapan pembukuan berbasis teknologi menggunakan perangkat lunak ini diharapkan nantinya usaha ini semakin maju dan berkembang. Selain ini juga di harapkan, kegiatan ini mampu membantu pekerjaan terkait pembukuan dengan cepat dan akurat. Pada tahap terakhir, yaitu tahap evaluasi dan monitoring. Pada tahap ini dilakukan metode coaching, dimana pemilik memperlihatkan progress dengan menceritakan hambatan dan kesulitan yang dihadapi dalam melakukan proses pembukuan menggunakan perangkat lunak. Adapun sasaran dari kegiatan ini adalah: 
1. Membantu memperbaiki system pembukuan sesuai dengan standar akuntansi berbasis UMKM.

2. Membantu UMKM dalam mengoperasikan system pembukuan terkomputerisasi

3. Delapan puluh persen pekerjaan mitra terbantu dengan cepat dan akurat.

4. Membantu mitra memiliki data keuangan yang valid sesuai dengan kondisi saat ini.

5. Membiasakan mitra melakukan pembukuan dengan benar, cepat dan tepat serta mitra mampu menganalisis kondisi usahanya untuk kemajuan dimasa yang akan datang.

6. Mitra mampu menggunakan data keuangan sebagai dasar pengambilan keputusan ekonomis.

Prosedur Kerja

Pada pengabdian kepada masyarakat ini dilakukan prosedur kerja sebagai berikut:

Tabel 2. Prosedur Kerja

\begin{tabular}{|l|l|l|}
\hline \multicolumn{1}{|c|}{ Tahapan } & \multicolumn{1}{|c|}{ Metode } & \multicolumn{1}{c|}{ Keterangan } \\
\hline Tahap Awal & $\begin{array}{l}\text { 1. Survey } \\
\text { 2. Wawancara }\end{array}$ & $\begin{array}{l}\text { Memperoleh gambaran } \\
\text { awal dan permasalahan } \\
\text { yang dihadapi mitra }\end{array}$ \\
\hline Tahap Pelaksanaan & $\begin{array}{l}\text { 1. Pelatihan } \\
\text { 2. Demontrasi Kegiatan } \\
\text { 3. Pendampingan }\end{array}$ & $\begin{array}{l}\text { Peserta memperoleh } \\
\text { transfer ilmu dan simulasi } \\
\text { penggunaan aplikasi }\end{array}$ \\
\hline Tahap akhir & $\begin{array}{l}\text { Evaluasi dan Monitoring } \\
\text { mitra }\end{array}$ & $\begin{array}{l}\text { Diharapkan mitra dapat } \\
\text { mengaplikasikan ilmu } \\
\text { mengenai pembukuan } \\
\text { melalui aplikasi perangkat } \\
\text { lunak }\end{array}$ \\
\hline
\end{tabular}

\section{Partisipasi Mitra}

Mitra dalam hal ini adalah pemilik usaha dan pengelola usaha yaitu ibu Candra Wita dan Lili. Parsipasi mitra dalam kegiatan ini adalah:

1. Menyediakan tempat dan peralatan untuk kegiatan pelatihan.

2. Memiliki keinginan dan motivasi untuk mengikuti kegiatan pelatihan mengenai pembukuan demi keberlangsungan usaha dimasa yang akan datang.

3. Ikut terlibat dalam simulasi pembukuan menggunakan aplikasi MYOB. 


\section{Evaluasi Program dan Keberlanjutan Program}

Evaluasi dilakukan secara langsung pada saat simulasi selama kegiatan berlangsung. Tujuan evaluasi ini adalah untuk perbaikan pelaksanaan berikutnya dan seandainya ada hambatan, maka akan didiskusikan dengan mitra untuk mencarikan solusi dan perbaikannya. Diharapkan ke depan akan terjalin kerjasama antara mitra dengan Politeknik Negeri Padang.

\section{Analisis Kebutuhan Mitra}

Kebutuhan mitra adalah sebagai berikut:

1. Membutuhkan pengetahuan dan pemahaman mengenai teknik pembukuan yang cocok untuk usaha tersebut.

2. Membutuhkan keterampilan dalam menggunaan aplikasi MYOB.

3. Membutuhkan bimbingan dalam mengikuti perubahan digital untuk mampu bertahan dan mengembangkan usaha menggunakan media elektronik.

\section{Hasil}

Adapun hasil yang telah diperoleh dari kegiatan ini adalah:

1. Peningkatan ilmu terkait dengan pembukuan keuangan menggunakan aplikasi MYOB.

2. Peningkatan keterampilan dalam menguasai aplikasi MYOB.

3. Adanya pembukuan yang jelas terkait hasil usaha yang dijalani.

4. Proses pengambilan keputusan berdasarkan dengan pembukuan.

\section{Ucapan Terima Kasih}

1. Politeknik Negeri Padang yang telah memberikan kesempatan dan bantuan dalam menyelesaikan kegiatan ini.

2. Bapak Surfa Yondri, ST.,S.ST.,M.Kom selaku Direktur Politeknik Negeri Padang.

3. Bapak Dr. Yuhefizar, S.Kom., M.Kom selaku Kepala P3M Politeknik Negeri Padang.

4. Ibu Dr. Amy Fontanella, SE.,M.Si.,Ak selaku Ketua Jurusan Akuntansi Politeknik Negeri Padang.

5. Rekan-rekan Jurusan Akuntansi Politeknik Negeri Padang.

\section{Referensi}

Modugo,K.P.,\&Eragable,E.(2018). Implementation of IFRS Adoption for SMEs in Nigeria. Fountain Journal of Management and Social Sciences, 2 (1)36-46

Anonim. (2019, 21 Des). "Kontribusi Ekonomis Kreatif terhadap PDB Indonesia”. Diperoleh tanggal 2 Februari 2020 dari: (http://kompas.id/baca/adv_post/kontribusiekonomi-kreatif -terhadap-pdb-indonesia//)).

Modul computer akuntansi MYOB V.25 